\title{
Ambilobea, a new genus from Madagascar, the position of Aucoumea, and comments on the tribal classification of the frankincense and myrrh family (Burseraceae)
}

\author{
Mats Thulin, Björn-Axel Beier, Sylvain G. Razafimandimbison and Hannah I. Banks
}

M. Thulin (mats.thulin@ebc.uu.se), Dept of Systematic Biology, EBC, Uppsala Univ., Norbyvägen 18D, SE-752 36 Uppsala, Sweden.-B.-A. Beier, County Administrative Board of Stockholm, Box 22067, SE-104 22 Stockholm, Sweden. - S. G. Razafimandimbison, Dept of Botany, Bergius Foundation, Stockholm Univ., SE-106 91 Stockholm, Sweden. - H. I. Banks, Micromorphology Section, Jodrell Laboratory, Royal Botanic Gardens, Kew, Richmond, Surrey TW9 3DS, UK.

\begin{abstract}
Phylogenetic analyses of 46 species, representing all tribes and 14 out of 18 recognized genera of Burseraceae, are performed using nuclear ETS and plastid rps16 sequences. Boswellia madagascariensis, the only Malagasy species of this genus, is shown to belong to a clade comprising all sampled members of the current tribe Canarieae plus Triomma, whereas other species of Boswellia (including the type, B. serrata) form a clade that is strongly supported as sister to Garuga. A new genus, Ambilobea, is proposed for B. madagascariensis and the new combination A. madagascariensis is made. Ambilobea differs from Boswellia s. s. by being dioecious and by having valvate petals and, furthermore, is unique in the family by its winged tips to the petioles, by having pyrenes that remain attached to the detached valves of the fruit at dehiscence, and by its long-spinose pollen grains. Aucoumea, a monotypic central African rain forest genus, is strongly supported as sister to a clade with the arid-adapted Bursera and Commiphora. Boswellia s. s. and Garuga form a clade characterized by having hermaphroditic flowers. The relationships within Burseraceae emerging from this and previous phylogenetic studies are, on several points, in conflict with current tribal delimitation.

The following suggestions for a new tribal classification of Burseraceae are made: 1) Beiselia, sister to the rest of the family, needs to be placed in a tribe of its own, Beiselieae, trib. nov., 2) Protieae should be restricted to Crepidospermum, Protium and Tetragastris, although generic rearrangements seem to be needed within this tribe, 3) Bursereae should be restricted to Aucoumea, Bursera and Commiphora, but generic rearrangements are needed in the Bursera-Commiphora complex, 4) the remaining genera, Ambilobea, Boswellia, Canarium, Dacryodes, Garuga, Haplolobus, Pseudodacryodes, Rosselia, Santiria, Scutinanthe, Trattinnickia and Triomma, are probably best placed in a broadly circumscribed Garugeae.
\end{abstract}

Burseraceae is a pantropical family of some 700 species in 18 genera, best known for its fragrant resins, such as frankincense from species of Boswellia and myrrh from species of Commiphora. However, the family also comprises important timber trees, such as Aucoumea klaineana (Gabon mahogany).

The family is generally subdivided into three tribes, Bursereae, Canarieae and Protieae, a classification that goes back to Lam (1932), but with some later modifications and additions of new genera (see Harley and Daly 1995 for an account of the taxonomic history of the family). In a recent study of the pollen morphology of Burseraceae (Harley et al. 2005), the predominantly African-Mesoamerican Bursereae was circumscribed to comprise Aucoumea, Beiselia, Boswellia, Bursera, Commiphora and Triomma, the predominantly Malesian Canarieae comprised Canarium, Dacryodes, Haplolobus, Pseudodacryodes, Rosselia, Santiria, Scutinanthe and Trattinnickia, whereas the predominantly South-American Protieae comprised Crepidospermum, Garuga, Protium and Tetragastris.
A first analysis of phylogenetic relationships within Burseraceae (Clarkson et al. 2002), based on sequence data from the intron of the plastid rps 16 gene, comprised samples from 11 genera, and showed the monotypic Mexican Beiselia to be sister to the rest of the family with strong support. Otherwise, Bursereae was found to be nonmonophyletic, with Boswellia sister to Garuga, a relationship that had already been anticipated due to similarities in their pollen morphology (Harley and Daly 1995).

A second and expanded phylogenetic study (Weeks et al. 2005) was based on both plastid rps16 and nuclear ETS data and comprised samples from 50 species in 13 genera. This study confirmed the position of Beiselia as sister to the rest of the family, as well as the sister relationship between Boswellia and Garuga, which, along with Triomma, grouped with Canarieae rather than with the other members of Bursereae. Still, no attempt to revise the tribal classification of the family was made, pending data from missing genera.

Our interest in the phylogeny of Burseraceae was triggered in the first place by the species Boswellia 
madagascariensis, which, for morphological reasons, did not seem to fit in its genus and did not appear to have any other obvious relatives in the family either. We also wanted to include Aucoumea in a phylogeny, as this monotypic central African genus has sometimes been associated with Boswellia (Engler 1931, Harley and Daly 1995), but with doubtful justification. Our main aims with this study are (1) to establish the phylogenetic relationships of Boswellia madagascariensis and Aucoumea by including them in an analysis comprising samples from all 13 previously studied genera, and particularly with a wide and representative sampling of other species of Boswellia, (2) to propose a new classification for the anomalous Boswellia madagascariensis, and (3) to make suggestions for a new tribal classification of the family based on the monophyletic entities now emerging.

\section{Material and methods}

\section{Taxon sampling}

We sampled from 14 out of the 18 currently recognized genera of Burseraceae (Harley et al. 2005), including representatives of all tribes, the missing genera being Haplolobus, Pseudodacryodes, Rosselia and Scutinanthe, which are all placed in Canarieae. A total of 46 species of Burseraceae were included in the analyses, and for larger genera the sampling was made, as far as possible, to comprise species from different parts of their areas of distribution. For Boswellia 14 out of about 20 species were sampled, including species from the African continent, Socotra, Madagascar and India. Two accessions of the dioecious $B$. madagascariensis were included, one female and one male. Also of the monotypic Beiselia, sister to the rest of the family in previous studies, an additional terminal was included, using a previously published $r p s 16$ sequence and an ETS sequence of our own (Appendix 1), making the total number of terminals in the ingroup 48 .

Two species of Anacardiaceae, Pistacia mexicana and Rhus trilobata, were used as outgroups, as this family has been identified as sister to Burseraceae in broader analyses (Gadek et al. 1996). Available sequence data were downloaded from GenBank. Voucher information and accession numbers for all sequences used are provided in Appendix 1.

\section{DNA extraction, amplification and sequencing}

DNA was extracted using a slightly modified version of the $2 \times$ CTAB method of Doyle and Doyle (1987). The DNA from silica-gel-dried material was precipitated with ethanol, and the DNA from herbarium material was precipitated in isopropanol, following the recommendations of Fay et al. (1998). DNA was purified using the QIA-quick purification kit following the manufacturer's protocol.

Two markers were used for this study, the nuclear ribosomal external transcribed spacer (ETS) and the plastid rps16 intron, which both have been shown to be useful for inferring phylogenetic relationships within Burseraceae (Clarkson et al. 2002, Becerra 2003, Weeks and Simpson 2004, 2007, Weeks et al. 2005). One sequence is missing from the data matrix, rps16 of male Boswellia madagascariensis, due to non-amplification.
Protocols for amplifying the selected regions via polymerase chain reaction (PCR) followed those outlined by Weeks et al. (2005). In all PCRs, one reaction was run with water only as a negative control. PCR products were purified using the QIAquick purification kit or the MultiScreen PCR-plates, according to the manufacturer's protocols. Cycle sequencing was done using the Dye Terminator Cycle Sequencing kit ver. 1.0 or with the DYEnamic ET terminator Cycle Sequencing Kit. The sequencing reactions were subsequently run on a MegaBACE 1000 capillary machine.

\section{Phylogenetic analyses}

Sequence fragments were assembled and edited using the Sequencher (Gene Codes Corporation) software package. For each marker all new sequences and the published ones from GenBank were aligned together using the computer program CLUSTAL-X (Thompson et al. 1997) to produce an initial alignment that was manually adjusted using the software Se-Al ver. 2.0 (Rambaut 1996). The aligned matrices are available upon request from the authors. Insertion/deletion events were inferred by eye and gaps were treated as missing data in the alignments. Unambiguous insertions and deletions (indels) were coded as binary characters $(0$ and 1$)$.

The ETS and rps16 data (including all coded indels) of the 48 and 47 Burseraceae terminals, respectively, were separately analyzed with parsimony jackknifing (Farris et al. 1996), implemented in PAUP* ver. 4.0b10 (Swofford 1998), to detect the presence of any well-supported topological conflicts. The following settings were used: a deletion frequency of $37 \%$, emulate 'jac' resampling option on, 10000 replicates, MULTREES option off, nearest neighbor interchanges (NNI) branch swapping, and five random addition sequences. A combined parsimony analysis of the 48 Burseraceae terminals was subsequently performed using the following settings: heuristic search option, 5000 random sequence additions, tree bisectionreconnection (TBR) branch swapping, and MULTREES option on. The consistency index (CI; Kluge and Farris 1969) and retention index (RI; Farris 1989) were calculated (all uninformative characters excluded) to estimate homoplasy. Jackknife (JK; Farris et al. 1995) values were computed using heuristic searches, with MULTREES off, NNI branch swapping, five random additions, and 10000 replicates to assess relative support of retained clades. A strict consensus tree was produced from the resulting most parsimonious trees (MPT) saved from the combined analysis.

A combined Bayesian analysis of sequence data (all coded indels included) from the ETS and rps16 regions of the 48 Burseraceae terminals was performed using MrBayes 3.1 (Huelsenbeck and Ronquist 2001, Ronquist and Huelsenbeck 2003). For each single gene data set, the best performing nucleotide substitution model was selected using the computer program MrModeltest 2.0 (Nylander 2004). In the latter, the best performing evolutionary model was estimated under three different model selection criteria: Akaike information criterion (AIC) (Akaike 1974), AICc (a second order AIC, necessary for small samples) and the 
Bayesian information criterion (BIC) (Schwartz 1978). The combined Bayesian analysis was conducted with four independent Markov chains run for $5 \times 10^{6}$ Metropoliscoupled MCMC generations, with tree sampling every $1 \times$ $10^{3}$ generations, and burn-in after $2 \times 10^{5}$ trees (as detected by plotting the $\log$ likelihood scores against generation number). We partitioned the combined data sets into two partitions: partition no. 1 with GTR $+\mathrm{G}$ applied to the rps 16 data; and partition no. 2 with GTR $+\mathrm{G}+\mathrm{I}$ applied to the ETS data. Partitions were unlinked so that each data set was allowed to have its own sets of parameters. Flat prior probabilities were specified according to suggestions produced by the software MrModeltest 2.0 (Nylander 2004). The combined Bayesian analysis was repeated two times using different random starting trees to evaluate the convergence of the likelihood values and posterior probabilities. All saved trees (after excluding burn-ins) from the two independent runs were pooled for a consensus tree. Groups characterized by posterior probabilities (PP) over $95 \%$ were regarded as strongly supported.

\section{Pollen morphology}

Mature, unopened buds of Boswellia madagascariensis (from Razafimandimbison and Andrianantoanina 449, UPS) were dissected in a $1 \%$ solution of Libsorb and then acetolysed (Erdtman 1960). Pollen was prepared for light microscopy (LM) by mounting in glycerol jelly, then measured using a Nikon Labophot LM, and photographed using a Leica DMRB LM fitted with an Olympus digital camera. For scanning electron microscopy (SEM), acetolysed exines in $90 \%$ ethanol were pipetted onto stubs and allowed to air dry before coating with platinum. They were examined and photographed using a Hitachi S4700 FE-SEM. Terminology follows Punt et al. (1994).

\section{Results}

Information on data sets and resulting trees for the parsimony analyses are presented in Table 1. A total of 99 sequences were used, of which 33 are published here.

Separate parsimony jackknifing analyses of the rps 16 and the ETS data produced trees with a similar topology (not shown), although the rps16 tree was considerably more resolved. Visual inspection of the trees showed no well-

Table 1. Comparison of rps16, ETS, and combined data sets and resulting trees for parsimony analyses of Burseraceae. $\mathrm{PIC}=$ parsimony informative character, MPT =most parsimonious tree.

\begin{tabular}{lccc}
\hline & $r p s 16$ & ETS & Combined rps16/ETS \\
\hline $\begin{array}{l}\text { Number of sequences } \\
\quad \text { used }\end{array}$ & 49 & 50 & 99 \\
Lengths of aligned & 1028 & 421 & 1449 \\
$\quad$ matrices & & & \\
Number of PICs & 166 & 215 & 381 \\
$\quad$ Number of coded & 7 & 0 & 7 \\
$\quad$ indels & 281 & 804 & 1152 \\
Lengths of MPT & 0.733 & 0.439 & 0.514 \\
Consistency index & 0.900 & 0.670 & 0.752 \\
Retention index & & & \\
\hline
\end{tabular}

supported conflict between them and, accordingly, we merged the rps 16 and ETS data for combined analyses.

The merged data set yielded 1438 positions, of which 381 (including seven coded indels from the $r p s 16$ data) were parsimony informative (Table 1). A parsimony analysis of the combined data produced 57 MPTs. The strict consensus tree of these was more resolved and had higher support values than any of the trees from the separate analyses (not presented). The topology of the strict consensus tree was also entirely congruent with that of the Bayesian majority rule consensus tree (Fig. 1) from a Bayesian analysis of the same combined data set. Therefore, both jackknife support from the parsimony analysis and Bayesian posterior probabilities are shown on the tree in Fig. 1. The phylogram depicted in Fig. 2 is one randomly selected of the 57 MPTs from the combined analysis. It shows particularly long branches leading to the two terminals of Beiselia mexicana (61 changes), the two species of Trattinnickia (48 changes), and to the two terminals of Boswellia madagascariensis (38 changes).

For results of the pollen morphological study, see below under Ambilobea.

\section{Discussion}

Our combined analyses (Fig. 1) indicate with strong support (JK 99; PP 1.00) that the monotypic Mexican genus Beiselia, represented by two terminals (clade A) and found on the longest branch (61 changes) in the phylogram (Fig. 2), is sister to the rest of the sampled Burseraceae, which corroborates previous results by Clarkson et al. (2002) and Weeks et al. (2005). Beiselia is also morphologically distinctive and we suggest that it is best accommodated in a tribe of its own (below).

Clade B, the Protium clade, largely corresponds to the tribe Protieae and is also strongly supported (JK 100; PP 1.00). As in the analysis by Weeks et al. (2005), the Protium clade consists of Crepidospermum, Protium and Tetragastris, whereas Garuga, traditionally regarded as a member of Protieae, does not belong here. Our results indicate that Protieae may be sister to the rest of Burseraceae, except Beiselia, but the support is not strong (JK 76; PP 0.63). In the study by Weeks et al. (2005), Protieae instead was weakly supported as sister to the tribe Bursereae s. s. Protium itself was shown to be non-monophyletic in the study by Weeks et al. (2005), and so it is here (Fine et al. 2005).

Clade C, the Bursera clade, is strongly supported (JK 99; PP 1.00) and comprises Aucoumea, Bursera and Commiphora, thus corresponding to tribe Bursereae in a restricted sense (with Beiselia, Boswellia and Triomma removed). The presently paraphyletic Bursera, and Commiphora, have long been regarded as closely related, but the position of the monotypic African Aucoumea has been more uncertain, even if Harley et al. (2005) pointed to some pollen morphological similarities between these three genera. With its extrastaminal disk and dry fruits with a distinct columella, Aucoumea differs markedly from Bursera and Commiphora. It was also long believed to have hermaphroditic flowers (Engler 1931), but the flowers were shown to be unisexual by Grison (1978), thus agreeing with 


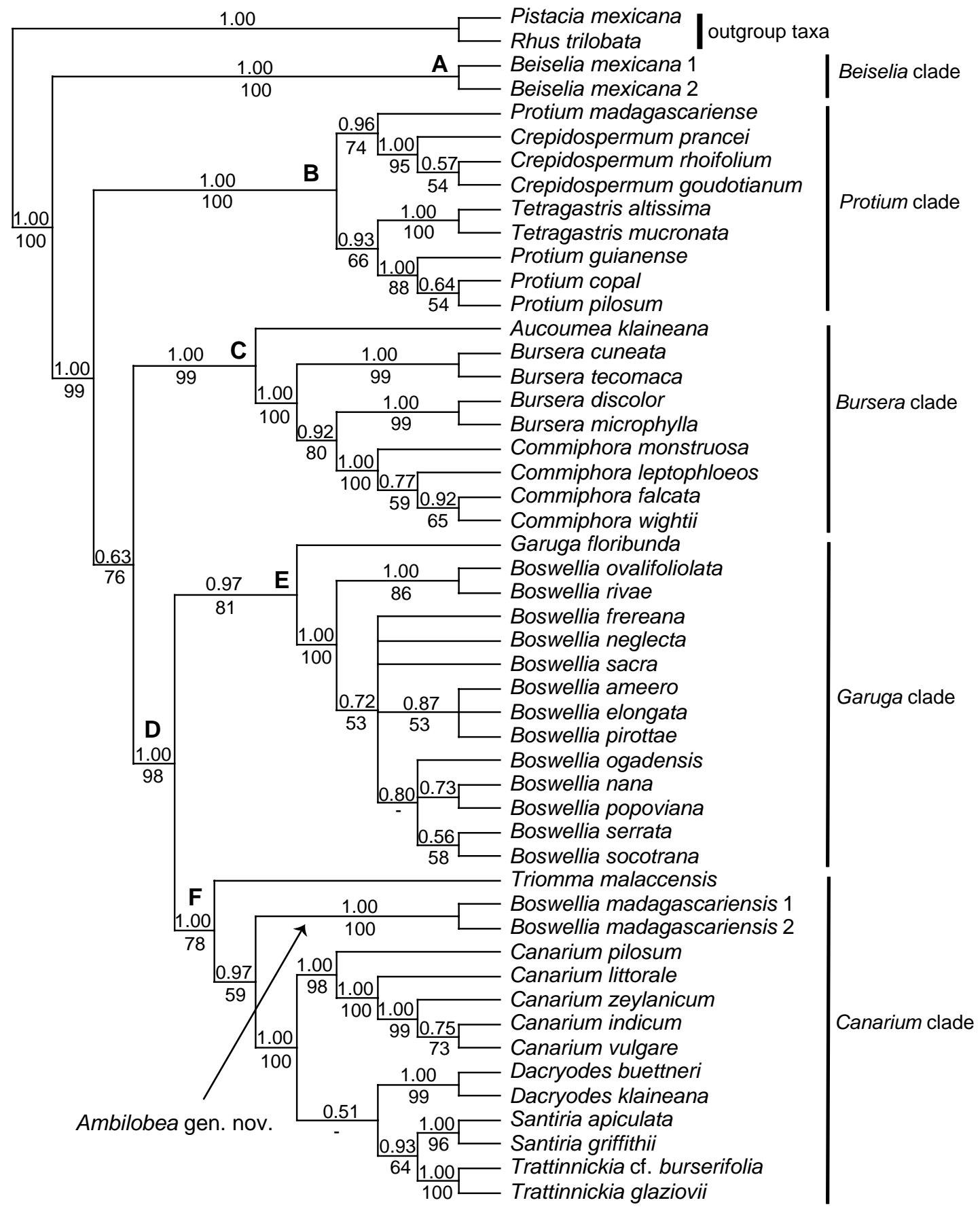

Figure 1. Bayesian majority rule consensus tree from the combined rps16/ETS analysis with Bayesian posterior probabilities shown above and jackknife support below the branches. Capital letters designate clades that are discussed in the text.

Bursera and Commiphora, as well as with most other members of the family.

Clade D comprises all the remaining genera sampled and is strongly supported (JK 98; PP 1.00), with clade E (the Garuga clade, with Garuga plus Boswellia, all species sampled except $B$. madagascariensis) as a well supported subclade (JK 81; PP 0.97). All sampled members of the tribe Canarieae (Canarium, Dacryodes, Santiria and Trattinnickia) form another subclade ( $\mathrm{F}$, the Canarium clade) with strong support (JK 78; PP 1.00), along with the monotypic Asian Triomma, as well as with Boswellia madagacariensis, represented by two terminals. In the
Bayesian analysis Boswellia madagascariensis is strongly supported (PP 0.97) as sister to the Canarieae s. s., but this position has only weak jackknife support (JK 59). A clade with Canarieae plus Triomma was also recovered by Clarkson et al. (2002) and Weeks et al. (2005). The branch leading to Boswellia madagascariensis is one of the longest (38 changes) in the phylogram (Fig. 2), and we propose to accommodate this species in a genus of its own, Ambilobea (below).

Clade E, the Garuga clade, with Garuga and Boswellia s. s., is characterized by all members having hermaphroditic flowers. Otherwise, members of Burseraceae generally have, 


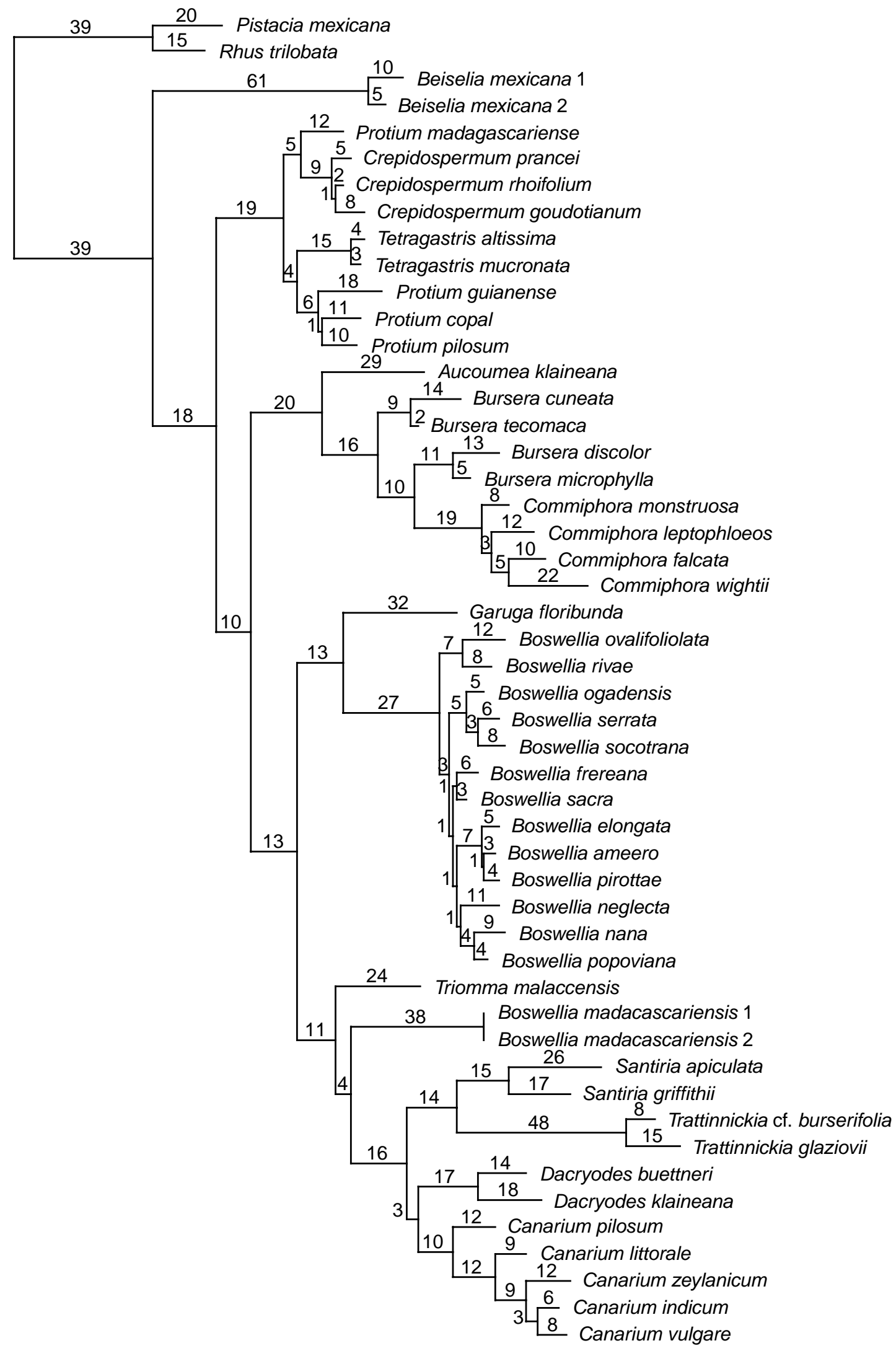

10 changes

Figure 2. Phylogram of one of the most parsimonious trees from the combined rps 16/ETS analysis. Numbers of inferred character changes are shown above the branches and are proportional to the branch lengths. 
more or less clearly, functionally unisexual flowers and this is true also for Boswellia madagascariensis, which is dioecious, as well as for Triomma, and for Canarieae as currently circumscribed, except in a number of neotropical Dacryodes species (Daly and Martínez-Habibe 2003). Clade $\mathrm{E}$, as well as lineages within Dacryodes, therefore seems to provide examples of plants with hermaphroditic flowers being evolved from ancestors with functionally unisexual flowers. Pollen morphological similarities between Boswellia and Garuga were also pointed out by Harley and Daly (1995) and Harley et al. (2005). Our sampling of Boswellia, besides the excluded $B$. madagascariensis, comprises species from the African continent, Socotra and India (including the type of the genus, $B$. serrata), but resolution within the genus is poor and not much can be said about, for example, biogeographical and taxonomical implications of the phylogeny at this stage. However we hope to include more markers and more species in a forth-coming phylogenetic study focusing on this genus.

\section{Ambilobea}

\section{Ambilobea Thulin, Beier \& Razafim. gen. nov.}

A Boswellia Roxb. floribus unisexualibus (planta dioecia) et petalis valvatis, a Triomma Hook. f. androecio diplostemono, disco intrastaminali et fructibus non-lignosis sine alis, et ab ambobus petiolis apice alatis et pyrenis ad valvas fructus dehiscenti affixis differt.

Type: Ambilobea madagascariensis (Capuron) Thulin, Beier \& Razafim.

Trees or shrubs, up to $20 \mathrm{~m}$ tall, glabrous, dioecious; trunks grey with longitudinal fissures; resin fragrant. Leaves alternate, \pm densely clustered at shoot apices, imparipinnate, (3-)5-9foliolate, (5-)10-20(-25) cm long; petiole 20-50 mm long, slender, at the apex with a pair of wings $0.5-3 \mathrm{~mm}$ wide, truncate to rounded above, attenuate to auriculate below, sometimes \pm unequal; rhachis glabrous, not winged; leaflets subsessile, opposite, 35-90 × 7-12(-20) mm, lanceolate, \pm falcate, pinnately veined, the proximal ones proportionally shorter and wider, acuminate at the apex, rounded or broadly cuneate and \pm asymmetric at the base, with entire or shallowly serrulate margins. Inflorescences axillary, produced with the leaves, the male inflorescences dichasial much-branched pedunculate cymes (2-)5-12 cm long, the female inflorescences few-flowered pedunculate racemes or panicles $1-10 \mathrm{~cm}$ long; pedicels ca $2 \mathrm{~mm}$ long; bracts minute, triangular, ciliolate. Flowers (4-)5-merous, 3.5-5.0 $\mathrm{mm}$ in diameter; receptacle broadly cup-shaped; calyx-lobes ca $0.5 \mathrm{~mm}$ long, broadly triangular, valvate in bud; petals greenish, valvate in bud, spreading in open flowers, ca 1.6-2.0 $\times 0.8-1.4 \mathrm{~mm}$, ovate-triangular, with an acute outcurved apex; disk intrastaminal, annular, fleshy, glabrous, (8-)10-lobed, concave; male flowers with (8-)10 stamens inserted at the base of and between the lobes of the disk, 1.1-1.4 mm long, the ones alternating with the petals often slightly longer than the ones opposite to the petals, anthers yellow, $0.4-0.8 \mathrm{~mm}$ long, filaments narrowly triangular, pistillode $0.6-0.7 \mathrm{~mm}$ long; female flowers with staminodes $0.8-1.0 \mathrm{~mm}$ long with narrow anthers, pistil ca $1.5 \mathrm{~mm}$ long, glabrous, ovary 3-locular, each locule with 2 collateral ovules, style thick and short with a capitate, obscurely 3-lobed stigma. Fruit a 3-locular triangular pseudocapsule, $25-32 \times \mathrm{ca} 10 \mathrm{~mm}$, narrowly pyriform, glabrous, the central columella with 3 wings up to $3 \mathrm{~mm}$ wide at the widest point; pyrenes 3 , free from each other, 1seeded, ca $5 \times 4-5 \mathrm{~mm}$, triangular, flattened, acute at the apex, not winged, remaining attached to the detached valves of the fruit at dehiscence, endocarp bony; seed triangular with thin testa, embryo with cotyledons divided and much folded.

Genus of a single species restricted to northern Madagascar. The name Ambilobea is derived from Ambilobe, a Malagasy town with several localities of the plant, including the type locality, in its vicinity.

\section{Ambilobea madagascariensis (Capuron) Thulin, Beier \& Razafim. comb. nov. (Fig. 3, 4)}

Basionym: Boswellia madagascariensis Capuron, in Adansonia, n. s. 2 (1962, p. 268).

Type: Madagascar, Massif d'Andavakoera, north of Angodromena along the Ambilobe-Vohémar road, 11 Nov 1958, fl and immature fr, Capuron 18944-SF (holotype: $\mathrm{P}, 3$ sheets, isotype: TEF).

\section{Distribution and habitat}

Ambilobea madagascariensis is restricted to the northernmost tip of Madagascar, where it grows in dry deciduous forests on limestone escarpments and rocks, or on sand, at up to $500 \mathrm{~m}$ a.s.l.

\section{Additional specimens examined}

Madagascar. Andramaimbo northwest of Diégo-Suarez, 28 Nov 1958, male fl, Capuron 20136-SF (P, TEF), female fl and immature fr, Capuron 20137-SF (P, TEF); Montagne des Français, Massif d'Anosiravo, 13 Feb 1962, male fl, Capuron 20916-SF (P, TEF), 26 Apr 1963, fr, Capuron 22721-SF (P, TEF); Massif d'Amongoaba west of DiégoSuarez, 26 Jan 1966, male fl, Capuron 24449-SF (P, TEF); Sahafary in the Saharaina basin southeast of Diégo-Suarez, 27 Feb 1953, male fl, Capuron 7025-SF (P, TEF), 27 Nov 1958, male fl, Capuron 20121-SF (P, TEF); Ankarana Plateau, near Ambondromifehy, 27 Nov 1952, male fl, Capuron 6209-SF (P, TEF); Ankarana Plateau, Massif d'Ampatsoa, near confluence of Rodo R. and Andrafiamena R., 24 Dec 1963, male fl, Capuron 23148-SF (P, TEF), fr, Capuron 23149-SF (P, TEF); Sambirano, Massif d'Ambohipiraka (Ambilobe), 10 Mar 1964, sterile, Capuron 23411 bis-SF (P, TEF); Massif d'Andavakoera, north of Angodromena along the Ambilobe-Vohémar road, 11 Nov 1958, male fl, Capuron 18943-SF (P, TEF); Antsiranana, Antsiranana II, Analamerana Special Reserve, $12^{\circ} 54^{\prime} \mathrm{S}$, $49^{\circ} 35^{\prime} \mathrm{E}, 6-10$ Jan 2002, fr, Razafimandimbison, Andriambololonera \& Andrianantoanina 418 (K, MO, P, TAN, 


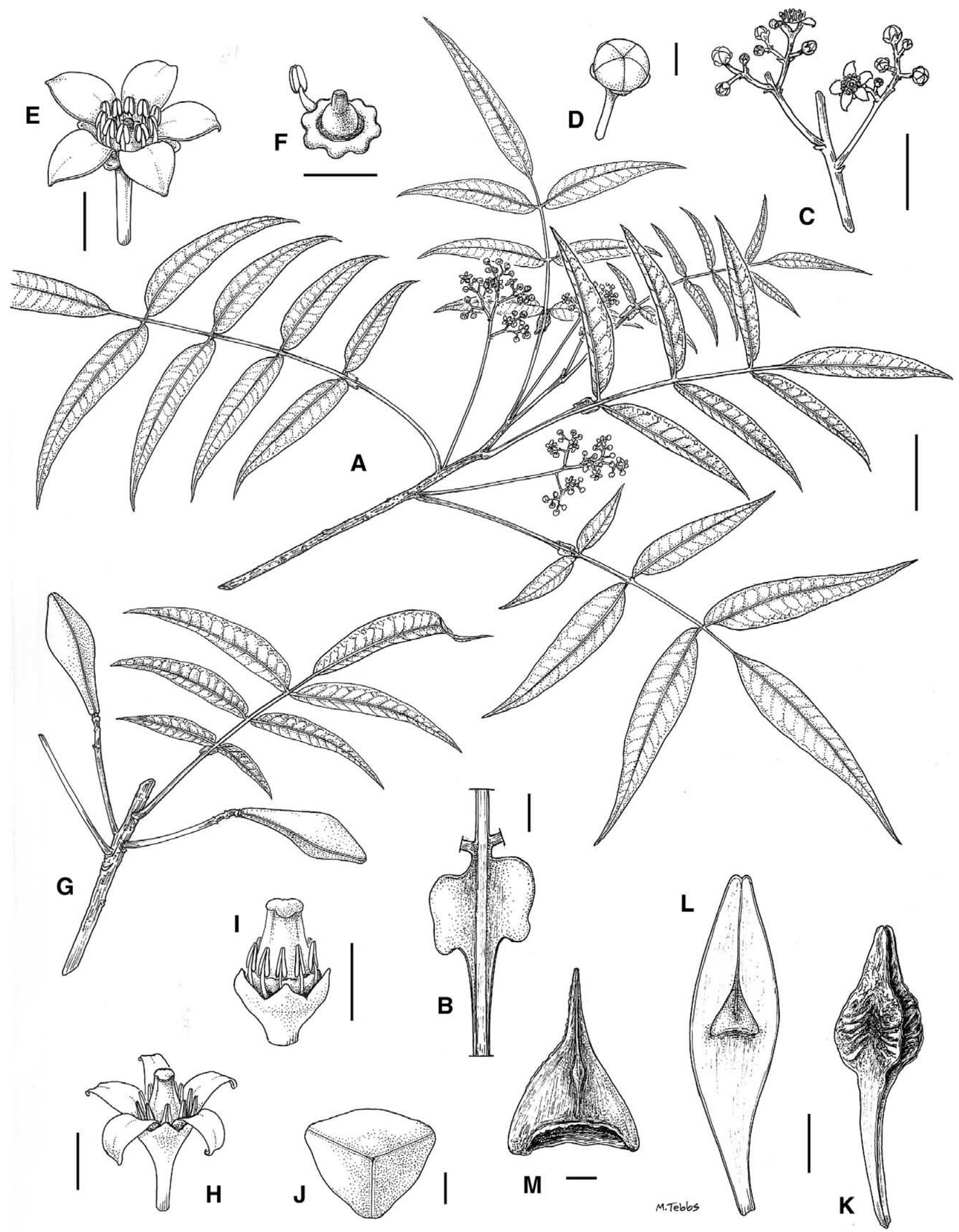

Figure 3. Ambilobea madagascariensis comb. nov. (A) branchlet of male tree in flower, (B) wings at top of petiole, (C) portion of male inflorescence, (D) bud of male flower, (E) male flower at anthesis, (F) disk of male flower, showing pistillode and one stamen, (G) branchlet of female tree in fruit, $(\mathrm{H})$ female flower at anthesis, (I) female flower with petals removed, (J) fruit in top view, (K) columella of fruit, (L) detached valve of fruit with adhering pyrene, (M) pyrene. Scale bars = $20 \mathrm{~mm}(\mathrm{~A}),(\mathrm{G}) ; 5 \mathrm{~mm}(\mathrm{C}),(\mathrm{K}),(\mathrm{L}) ; 2 \mathrm{~mm}(\mathrm{~B}),(\mathrm{J}) ; 1$ mm (D)-(F), (H), (I), (M). (A)-(F) from Razafimandimbison \& Andrianantoanina 449; (G), (J)-(M) from Razafimandimbison et al. 418; (H) and (I) redrawn from drawings by Godot de Mauroy in Capuron (1962). Drawn by Margaret Tebbs. 

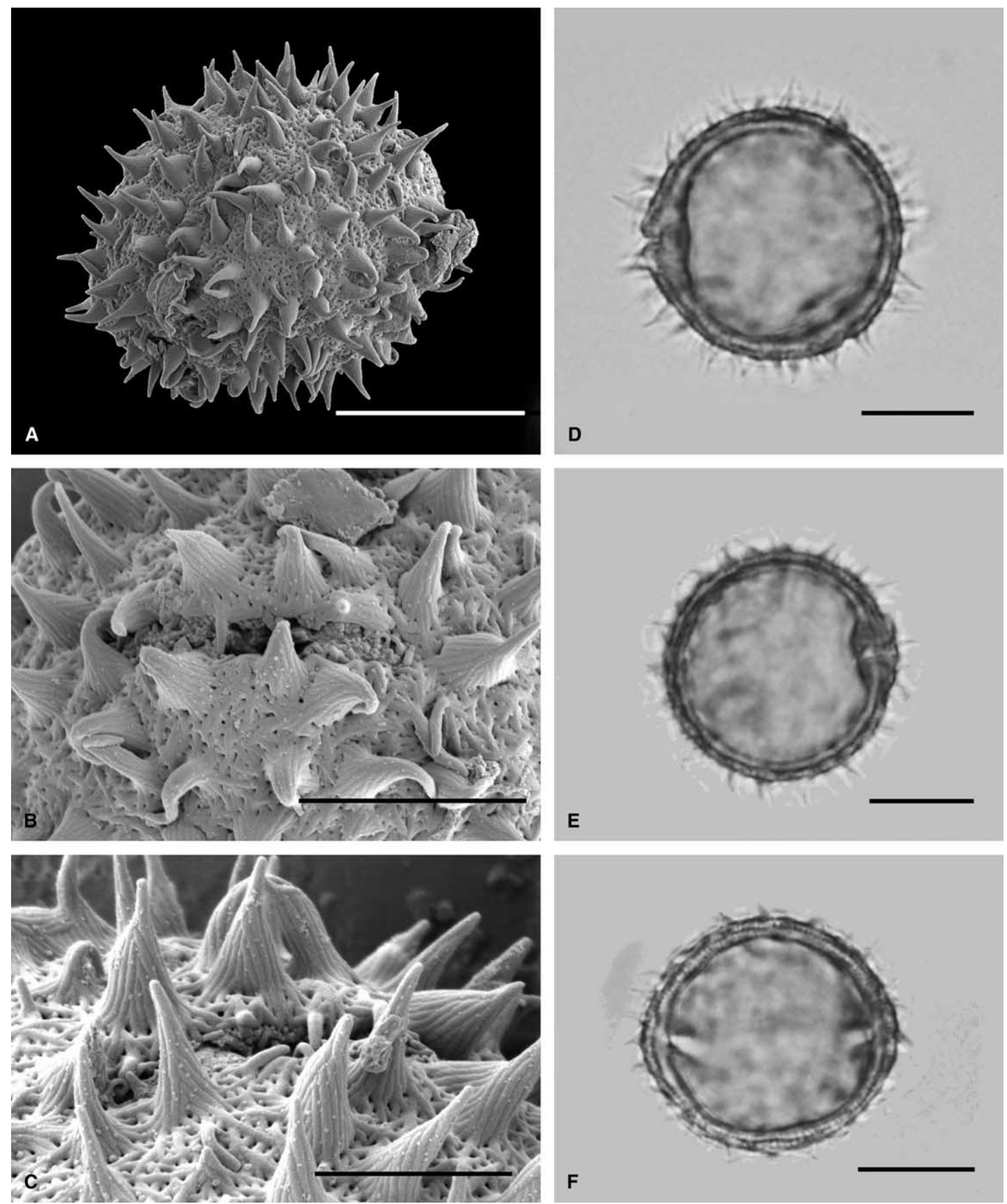

Figure 4. Pollen of Ambilobea madagascariensis. (A) whole grain showing spines and indistinct colpi (SEM), (B) close up of colpus (SEM), (C) close up of colpus and details of microreticulate surface and spines (SEM), (D)-(E) equatorial view of whole grains showing distinct costae around endoapertures and spinose exine (LM), (F) equatorial view of whole grain showing lalongate endoapertures (LM). Scale bars $=10 \mu \mathrm{m}(\mathrm{A}),(\mathrm{D})-(\mathrm{F}) ; 5 \mu \mathrm{m}(\mathrm{B}) ; 3 \mu \mathrm{m}(\mathrm{C})$.

UPS); Antsiranana, Ambilobe, Ankarana Special Reserve, $13^{\circ} 00^{\prime} \mathrm{S}, 49^{\circ} 15^{\prime} \mathrm{E}, 11-14$ Jan 2002 , male fl, Razafimandimbison \& Andrianantoanina 449 (K, MO, P, TAN, UPS).

\section{Taxonomic remarks}

Ambilobea madagascariensis was first described as a Boswellia, but already in the protologue (Capuron 1962) the alternative of placing the species in a genus of its own was mentioned. It was pointed out that the species differs from all other species of Boswellia by being dioecious and by having valvate petals, but Capuron still concluded that the species was best accommodated in this genus, stressing particularly the similarity of the fruit. Boswellia otherwise consists of some 19 species distributed in arid parts of tropical Africa, southwards to Tanzania, and extending to Socotra, the southern part of the Arabian peninsula and India.

Dioecy and valvate petals are characters that separate Ambilobea from Boswellia also today, all species of the latter having hermaphroditic flowers with imbricate petals. In 
addition, the dichasial male inflorescences of Ambilobea do not quite match anything found in Boswellia.

The characteristic winged tips to the petioles (Fig. 3B) found in Ambilobea are not matched in Boswellia or in any other member of Burseraceae. Winged leaf-rhachides and petioles are found in some species of Boswellia, as well as in species of some other genera of Burseraceae, such as Bursera, but the wings in these cases are never restricted to the tips of the petioles as in Ambilobea. Furthermore, various types of 'pseudostipules' or 'stipellae' are found on the leaves of species in some genera, such as Garuga and Canarium, and it is also possible that the petiolar wing of Ambilobea is another variation on that theme. In any case, the winged tips to the petioles of Ambilobea make the genus easily recognizable even in a vegetative state.

The pseudocapsules of Ambilobea superficially resemble the fruits of Boswellia, as mentioned above, but there also are important differences. From what can be deduced from the available material the pyrenes of Ambilobea remain attached to the detached valves of the fruit at dehiscence (Fig. 3L), and apparently the whole valve serves as an aid for wind dispersal of the pyrene. In Boswellia, the pyrenes are free and sometimes winged, and each pyrene by itself serves as a diaspore. In Fig. $1 / 11$ of Capuron (1962) is shown, according to the legend, "une face de la columelle avec un noyau". However, this is a misinterpretation. What is shown is a detached valve of the fruit with the pyrene adhering to it, exactly corresponding to our Fig. 3L. This kind of fruit, where the detached valve of the fruit and the attached pyrene together serve as a diaspore seems indeed to be unique in the family.

According to the molecular phylogeny (Fig. 1) Ambilobea and Boswellia are only fairly distantly related, and Ambilobea is instead sister to a group of genera constituting the previous tribe Canarieae and with Triomma as sister to Ambilobea plus Canarieae. Triomma resembles Ambilobea by being dioecious and having 5-merous flowers with valvate petals, and it has dry fruits dehiscing with three valves. However, the monotypic Triomma, which is confined to forests of western Malaysia, differs markedly from Ambilobea by, for example, its unwinged petioles, haplostemonous androecium, extrastaminal disk, woody and 3winged fruits, and by having diaspores in the form of broadly winged pyrenes. For a description of the pollen morphology in Ambilobea, and a comparison with pollen of Boswellia and Triomma (below).

\section{Pollen morphology}

Pollen isopolar, tricolporate, oblate spheroidal, with a circular outline in polar view (Fig. 4). Pollen size: P 25.4 (24-27) $\mu \mathrm{m}$, E 26.7 (25-29) $\mu \mathrm{m}$. Colpi indistinct, 6-9 $\mu \mathrm{m}$ long and less than $1 \mu \mathrm{m}$ wide (Fig. $4 \mathrm{~B}, \mathrm{C}$ ). Endoapertures lalongate (Fig. 4F), costae distinct (Fig. 4D-F). Exine tectate, microreticulate and spinose, with striate spines $1-3 \mu \mathrm{m}$ long (Fig. 4). Apocolpial wall excluding spines $1-2.5 \mu \mathrm{m}$ thick.

The pollen of Ambilobea is very different from that in Boswellia. Boswellia pollen was classified as the 'Garuga type' by Harley et al. (2005) and is very uniform throughout the genus. Ambilobea differs from this notably in shape (oblate spheroidal versus prolate spheroidal or subprolate), size (P 25.5, E 26.7 vs P 61.7, E 44.9), and ornamentation (spinose versus psilate-perforate). In the key to major pollen types in Burseraceae (Harley et al. 2005), the pollen of Ambilobea would key out as the 'Triomma type', unique for Triomma and characterized by its tectate, spinulose pollen. Pollen in Ambilobea and Triomma is similar (Fig. 5A-C, H, J in Harley et al. 2005), but Ambilobea differs clearly by its lalongate (not circular) endoapertures, and by having much longer and striate spines (spines up to $3 \mu \mathrm{m}$ vs up to ca $1 \mu \mathrm{m}$ long).

\section{Comments on tribal classification}

It is obvious from the discussion above that the relationships within Burseraceae emerging from this and previous phylogenetic studies are, on several points, in conflict with current tribal delimitation (Harley et al. 2005). Although our sample may seem small, it encompasses 15 out of the 19 genera now recognized in the family and, furthermore, at least 120 additional species, mainly of Bursera, Commiphora and Protium, have been sampled and analysed in other studies (Becerra 2003, Fine et al. 2005, Weeks et al. 2005, Weeks and Simpson 2007). All these additional species seem to conform well to the broad patterns presented here. We therefore want to make the following suggestions towards a new tribal classification of Burseraceae based on monophyletic entities.

\section{Clade A, the Beiselia clade}

This clade, which is with strong support sister to the rest of the family, only comprises the monotypic genus Beiselia. Forman et al. (1989) chose to treat Beiselia as a member of Bursereae, but pointed out that the genus in various respects is unique within the family. The most prominent features of Beiselia are the pointed protuberances (swollen petiole bases) on the branchlets and the 10(-12)-locular ovary with superposed ovules (the ovules are collateral in all other Burseraceae).

Daly in Harley and Daly (1995) placed Beiselia in his newly created Bursereae subtribe Boswelliinae along with Aucoumea, Boswellia and Triomma. This grouping was based solely on certain similarities in the fruits of these genera and ignored the profound differences between them in many other characters. In our study Boswelliinae sensu Daly is polyphyletic and its four genera belong to four different major clades (respectively, A, C, E and F). We propose instead that Beiselia is placed in a tribe of its own.

\section{Beiselieae Thulin, Beier \& Razafim. trib. nov.}

A tribubus ceteris familiae ramulis protuberationibus (basibus petiolorum) acutis persistentibus armatis et ovario $10(-12)$ loculato ovulis superpositis differt.

Type: Beiselia Forman. 


\section{Clade B, the Protium clade}

This clade comprises members of the genera Crepidospermum, Protium and Tetragastris and conforms to the current circumscription of the tribe Protieae Marchand (syn. Hedwigieae Marchand), except for the exclusion of Garuga, which is instead strongly supported as a member of clade D. Both Crepidospermum and Tetragastris appear to be nested within Protium (Fine et al. 2005, for a more comprehensive study of these taxa) and generic rearrangements seem to be needed.

We suggest that Protieae is restricted to Crepidospermum, Protium and Tetragastris. With the exclusion of Garuga the tribe will be more homogeneous, but still no obvious morphological synapomorphy for it seems to exist, and also pollen morphology is very variable (Harley and Daly 1995 , Harley et al. 2005).

\section{Clade C, the Bursera clade}

This clade comprises the monotypic Aucoumea along with members of Bursera and Commiphora and we suggest that the tribe Bursereae DC. is restricted to these genera. Currently also Beiselia, Boswellia and Triomma are referred to Bursereae, but this has no support in our study or in the study by Weeks et al. (2005). Harley and Daly (1995) regarded Garuga as 'a morphological outlier in the Protieae' and Weeks et al. (2005) transferred it to Bursereae, but again, this has no support in our analysis.

Bursera is paraphyletic (Weeks et al. 2005, Weeks and Simpson 2007), and generic rearrangements are obviously needed in the Bursera-Commiphora complex. The fleshy fruits, containing usually a single unwinged pyrene provided with a coloured pseudaril, of Bursera and Commiphora are very different from the dehiscent, dry fruit, with usually three, winged pyrenes in Aucoumea. No morphological synapomorphy for the tribe can be provided at present, but Harley et al. (2005) pointed to pollen morphological similarities between Bursera and Commiphora on the one hand, and Aucoumea and Commiphora on the other.

\section{Clade D, with the Garuga and Canarium clades}

This clade comprises all the remaining genera included in the analysis, Ambilobea, Boswellia, Canarium, Dacryodes, Garuga, Santiria, Trattinnickia and Triomma. It consists in turn of two subclades, clade E, the Garuga clade, with members of Garuga and Boswellia, and clade F, the Canarium clade, with the monotypic Triomma and Ambilobea along with members of Canarium, Dacryodes, Santiria and Trattinnickia. These four latter genera are currently included in the tribe Canarieae Engl., and this grouping is recovered also in our study as a subclade of clade F.

Canarieae in the sense of Harley et al. (2005) comprises also the Malesian-Pacific Haplolobus with some 15 species, the monotypic Pseudodacryodes in the Democratic Republic of Congo, the monotypic Rosselia on the Rossel Island near New Guinea, and Scutinanthe with two species and distributed from Sri Lanka to Sulawesi. These four genera have so far not been included in any molecular phylogenetic analysis. Haplolobus and the little-known Pseudodacryodes (only female plants are known) both have 3-merous flowers and it seems a reasonable assumption that they are related to the Canarium-Dacryodes complex. Forman in Forman et al. (1994), in the original publication of Rosselia, stated that this genus 'fits well into Canarieae on account of its trimerous flowers, fused pyrenes and folded cotyledons' and concluded that 'on the basis of the main characters used for generic distinction Rosselia comes closest to Dacryodes'. Scutinanthe, finally, differs from other Canarieae by having 5 -merous flowers, as well as very peculiar pollen (Harley et al. 2005), and is potentially misplaced. However, we prefer at present to just follow current praxis and assume that all these four genera belong in Canarieae.

A clade with Canarieae plus Triomma sister to a clade with Boswellia plus Garuga was recovered also by Weeks et al. (2005). Now we can add Ambilobea as a possible sister to the Canarieae (Discussion). If this clade (clade D) is treated as a tribe, the name Garugeae Marchand has priority over Boswellieae Engl. and Canarieae Engl. However, it is again a grouping that does not seem to have any morphological support at present.

An alternative classification would be to recognize a widely circumscribed Canarieae (clade F) as separate from a narrowly circumscribed Garugeae (clade E), comprising only Boswellia and Garuga. An argument for this would be that clade $\mathrm{E}$ has some morphological support, notably as regards to pollen morphology and hermaphroditic flowers (Discussion). On the other hand, there is scarcely any morphological support for Canarieae, especially now when Ambilobea and Triomma apparently would have to be added. Also, the combined group, Garugeae in a wide sense, has a stronger molecular support than its subgroups, and furthermore it seems advisable to keep the number of tribes low in this relatively small family. On balance, we therefore believe that clade $\mathrm{D}$, along with the missing genera Haplolobus, Pseudodacryodes, Rosselia and Scutinanthe, is probably best treated as a broadly circumscribed Garugeae.

\section{Conclusions}

Boswellia madagascariensis, the only Malagasy species of this genus, belongs to a clade comprising all sampled members of Canarieae plus Triomma, whereas other species of Boswellia (including the type, B. serrata), form a clade that is strongly supported as sister to Garuga. B. madagascariensis differs markedly from all other species of Boswellia by being dioecious and by having valvate petals. It also differs from all other members of Burseraceae by its winged tips to the petioles and by its pyrenes that remain attached to the detached valves of the fruit at dehiscence. The long, striate spines of the pollen grains are also unique in the family, although there is a certain similarity to the pollen of Triomma. The species is here placed in a genus of its own, Ambilobea gen. nov., endemic to northern Madagascar, and the new combination $A$. madagascariensis is made.

Aucoumea, a monotypic rain forest genus from central Africa not included in previous phylogenetic analyses of the family, is strongly supported as sister to the arid-adapted 
Bursera plus Commiphora. Boswellia (except B. madagascariensis) and Garuga form a clade that is characterized by having hermaphroditic flowers.

The relationships within Burseraceae emerging from this and previous phylogenetic studies are, on several points, in conflict with current tribal delimitation. Beiselia, sister to the rest of the family, needs to be placed in a tribe of its own, Beiselieae, trib. nov. Protieae is suggested to be restricted to Crepidospermum, Protium and Tetragastris, whereas Garuga should be excluded. Bursereae should be restricted to Aucoumea, Bursera and Commiphora, whereas all other genera, Ambilobea, Boswellia, Canarium, Dacryodes, Garuga, Haplolobus, Pseudodacryodes, Rosselia, Santiria, Scutinanthe, Trattinnickia and Triomma, are probably best placed in a broadly circumscribed Garugeae.

Acknowledgements - We are indebted to Lamidi Maroufath and Boris Vrskovy for material of some crucial species, to the Swedish Research Council for financial support to MT, and to Margaret Tebbs for the illustration in Fig. 3. We also wish to thank the Missouri Botanical Garden program, Madagascar, for arranging collecting permits for SR and the Association Nationale pour la Gestion des Aires Protégées (ANGAP) and Ministère des Eaux et Forêts (MEF) for issuing them, and Olivier Andrianantoanina and Sylvie Andriambololonera for assistance in the field.

\section{References}

Akaike, H. 1974. A new look at the statistical model identification. - IEEE Transactions on Automatic Control 19: 716-723.

Becerra, J. X. 2003. Evolution of Mexican Bursera (Burseraceae) inferred from ITS, ETS, and 5S nuclear ribosomal DNA sequences. - Mol. Phylogenet. Evol. 26: 300-309.

Capuron, R. 1962. Contributions a l'étude de la flore forestière de Madagascar. - Adansonia 2: 268-284.

Clarkson, J. J. et al. 2002. Phylogenetic relationships in Burseraceae based on plastid rps16 intron sequences. - Kew Bull. 57: 183-193.

Daly, D. C. and Martínez-Habibe, M. C. 2003. Notes on Dacryodes Vahl, including a new species from the Rio Negro basin in Amazonia. Studies in neotropical Burseraceae. XI. - Brittonia 54: 266-274.

Doyle, J. J. and Doyle, J. L. 1987. A rapid DNA isolation procedure for small quantities of fresh leaf material. - Phytochem. Bull. 19: 11-15.

Engler, A. 1931. Burseraceae. - In: Engler, A. and Prantl, K. (eds), Die Natürlichen Pflanzenfamilien (2nd ed.). W. Engelmann, 19a: 405-456.

Erdtman, G. 1960. The acetolysis method, a revised description. - Sv. Bot. Tidskr. 54: 561-564.

Farris, J. S. 1989. The retention index and rescaled consistency index. - Cladistics 5: 417-419.

Farris, J. S. et al. 1995. Constructing a significance test for incongruence. - Syst. Biol. 44: 570-572.
Farris, J. S. et al. 1996. Parsimony jackknifing outperforms neighbour-joining. - Cladistics 12: 99-124.

Fay, M. F. et al. 1998. Plastid $r b c L$ sequence data indicate a close affinity between Diegodendron and Bixa. - Taxon 47: 43-50.

Fine, P. V. A. et al. 2005. The contribution of edaphic heterogeneity to the evolution and diversity of Burseraceae trees in the western Amazon. - Evolution 59: 1464-1478.

Forman, L. L. et al. 1989. Beiselia mexicana (Burseraceae) and its affinities. - Kew Bull. 44: 1-31.

Forman, L. L. et al. 1994. Rosselia, a new genus of Burseraceae from the Louisiade Archipelago, Papua New Guinea. - Kew Bull. 49: 601-621.

Gadek, P. A. et al. 1996. Sapindales: molecular delimitation and infraordinal groups. - Am. J. Bot. 83: 802-811.

Grison, F. 1978. Note sur les fleurs de l'okoumé (Aucoumea klaineana Pierre, Burseraceae). - Adansonia ser. 2, 17: 335342.

Harley, M. M. and Daly, D. C. 1995. Burseraceae: Protieae. World pollen and spore flora 20. - Scandinavian Univ. Press.

Harley, M. M. et al. 2005. Pollen morphology and systematics of Burseraceae. - Grana 44: 282-299.

Huelsenbeck, J. P. and Ronquist, F. 2001. MrBayes: Bayesian inference of phylogenetic trees. - Bioinformatics 17: 754-755.

Kluge, A. G. and Farris, J. S. 1969. Quantitative phyletics and the evolution of anurans. - Syst. Zool. 18: 1-32.

Lam, H. J. 1932. The Burseraceae of the Malay archipelago and peninsula. - Bull. Jard. Bot. Buitenzorg. ser. 3, 12: 281-561.

Nylander, J. A. A. 2004. MrModeltest 2.0. Computer program distributed by the author. - Evolutionary Biology Centre, Uppsala Univ., Sweden.

Punt, W. et al. 1994. Glossary of pollen and spore terminology. - LPP Contr. Ser. 1. LPP Found., Utrecht < http://www. bio.uu.nl/ $\sim$ palaeo/glossary/ $>$.

Rambaut, A. 1996. Se-Al: sequence alignment editor. Computer program distributed by the author. - Univ. of Oxford.

Ronquist, F. and Huelsenbeck, J. P. 2003. MrBayes 3: Bayesian phylogenetic inference under mixed models. - Bioinformatics 19: $1572-1574$.

Schwartz, G. 1978. Estimating the dimensions of a model. - Ann. Stat. 6: 461-464.

Swofford, D. L. 1998. PAUP* Phylogenetic analysis using parsimony (*and other methods), ver. 4. - Sinauer.

Thompson, J. D. et al. 1997. The ClustalX windows interface: flexible strategies for multiple alignment aided by quality analysis tools. - Nucl. Acids Res. 25: 4876-4882.

Weeks, A. et al. 2005. The phylogenetic history and biogeography of the frankincense and myrrh family (Burseraceae) based on nuclear and chloroplast sequence data. - Mol. Phylogenet. Evol. 35: 85-101.

Weeks, A. and Simpson, B. B. 2004. Molecular genetic evidence for interspecific hybridization among Hispaniolan Bursera (Burseraceae). - Am. J. Bot. 91: 975-983.

Weeks, A. and Simpson, B. B. 2007. Molecular phylogenetic analysis of Commiphora (Burseraceae) yields insight on the evolution and historical biogeography of an 'impossible' genus. - Mol. Phylogenet. Evol. 42: 62-79. 
Appendix 1. Species sampled with voucher information and GenBank accession numbers. Sequences generated for this study are marked with an asterisk.

Aucoumea klaineana Pierre, Gabon, Maroufath s. n. (UPS), FJ233930*, FJ233911*. Beiselia mexicana Forman 1, Mexico, cultivated at NY Botanical garden, Pell s. n. (TEX), AY315112, AY314997. Beiselia mexicana 2, Mexico, cultivated at RBG Kew, Chase 639 (K), AJ416486; cultivated in Uppsala, Vrskovy s. n. (UPS), FJ233929*. Boswellia ameero Balf. f., Yemen, Socotra, Thulin \& Gifri 8776 (UPS), FJ233931*, FJ233912*. Boswellia elongata Balf. f., Yemen, Socotra, Thulin \& Gifri 8788 (UPS), FJ233932*, FJ233913*. Boswellia frereana Birdw., Somalia, Thulin \& Warfa 5599 (UPS), AY315084, AY314998. Boswellia madagascariensis Capuron 1, Madagascar, Razafimandimbison et al. 418 (UPS), FJ233933*, FJ233914*. Boswellia madagascariensis 2, Madagascar, Razafimandimbison \& Andrianantoanina 449 (UPS), FJ233915*. Boswellia nana Hepper, Yemen, Socotra, Miller \& Alexander 14298 (UPS), FJ233934*, FJ233916*. Boswellia neglecta S. Moore, Somalia, Thulin 10844 (UPS), FJ233935*, FJ233917*. Boswellia ogadensis Vollesen, Ethiopia, Thulin et al. 11328 (UPS), FJ233936*, FJ233918*. Boswellia ovalifoliolata Balakr. \& A. N. Henry, India, Vrskovy s. n. (UPS), FJ233937*, FJ233919*. Boswellia pirottae Chiov., Ethiopia, Gilbert \& Ermias 8349 (UPS), FJ233938*, FJ233920*. Boswellia popoviana Hepper, Yemen, Socotra, Miller et al. 10298 (UPS), FJ233939*, FJ233921*. Boswellia rivae Engl., Somalia, Thulin et al. 10433 (UPS), FJ233940*, FJ233922*. Boswellia sacra Flück., Somalia, cultivated in Uppsala, Thulin \& Warfa 5679 (UPS), FJ233941*, FJ233923*. Boswellia serrata Roxb., India, Vrskovy s. n. (UPS), FJ233942*, FJ233924*. Boswellia socotrana Balf. f., Yemen, Socotra, Thulin \& Gifri 8894 (UPS), FJ233943*, FJ233925*. Bursera cuneata Engl., Mexico, Weeks 99-VII17-1 (TEX), AY315045, AY315003. Bursera discolor Rzed., Mexico, Weeks 98-VII-15-1 (TEX), AY309305, AY309282. Bursera microphylla A. Gray, USA, Arizona, Weeks 01-X-08-2 (TEX), AF445934, AY309289. Bursera tecomaca (DC.) Standl., Mexico, Weeks 02-XII-09-01 (TEX), AY309359, AY309280. Canarium indicum L., Malaysia, Lai s. n. (BH), AY315113, AY315006. Canarium littorale Blume, Malaysia, Lai s. n. (BH), AY315117, AY315007. Canarium pilosum A. W. Benn., Malaysia,
Bogler s. n. (TEX), AY315120, AY315008. Canarium vulgare Leenh., Malaysia, Lai s. n. (BH), AY315123, AY315009. Canarium zeylanicum Blume, Malaysia, Lai s. n. (BH), AY315126, AY315010. Commiphora falcata Capuron, Madagascar, Phillipson et al. 3744 (MO), AY831875, AY831947. Commiphora leptophloeos (Mart.) J. B. Gillett, Bolivia, Becerra \& Venable 1010 (ARIZ), AF445953; Bolivia, Abbott 16295 (TEX), AY315016. Commiphora monstruosa (H. Perrier) Capuron, Madagascar, Phillipson 2728 (MO), AY831956; Madagascar, cultivated in USA, AF445955. Commiphora wightii (Arn.) Bhandari, India, Weeks 00-VIII-18-3 (TEX), AY315081, AY315020. Crepidospermum goudotianum Triana \& Planch., Bolivia, de Michel \& Capra 2439 (NY), AY964605, AY315021. Crepidospermum prancei Daly, Peru, Vásquez \& Jaramillo 6232 (MO), AY964606, AY315022. Crepidospermum rhoifolium (Benth.) Triana \& Planch., Venezuela, Delgado 759 (NY), AY964607, AY315023. Dacryodes buettneri (Engl.) H. J. Lam, Guinea, Carvalho 5748 (TEX), AY315140, AY315024. Dacryodes klaineana (Pierre) H. J. Lam, Merello et al. 1615 (MO), AY315143, AY315026. Garuga floribunda Decne., Indonesia, Sulawesi, Chase 2088 (K), AJ416479, FJ233926*. Pistacia mexicana H. B. \& K., USA, Texas, Weeks 01-X-08-5 (TEX), AY315146, AY315037. Protium copal (Schltdl. \& Cham.) Engl., Mexico, Killeen et al. 3136 (MO), AY315027, AY315105. Protium guianense (Aubl.) March., Suriname, Miller \& Hauk 9391 (MO), AY315028, AY315108. Protium madagascariense Engl., Madagascar, Schatz et al. 3616 (MO), AY315109, AY315029. Protium pilosum (Cuatrec.) Daly, Brazil, Gentry 49069 (MO), AY315096, AY315034. Rhus trilobata Nutt., USA, Texas, Weeks 01-X08-4 (TEX), AY315147, AY315038. Santiria apiculata A. W. Benn., Malaysia, Lai s. n. (BH), AY315129, AY315030. Santiria griffithii Engl., Malaysia, Lai s. n. (BH), AY315132, AY315031. Tetragastris altissima (Aubl.) Swart, Guyana, Polak 616 (MO), AY315150, AY315032. Tetragastris mucronata (Rusby) Swart, Bolivia, Killeen et al. 3136 (MO), AY315093, AY315033. Trattinnickia cf. burserifolia Mart, Guyana, Hoffman et al. 694 (TEX), AY315135, AY315036. Trattinnickia glaziovii Swart, Brazil, Gentry \& Revilla 69141 (MO), AY315138, FJ233927*. Triomma malaccensis Hook. f., Indonesia, Maluku, cultivated, Chase 2091 (K), AJ416478, FJ233928*. 